\title{
¿S Research Square

\section{Pharmacokinetics and Diuretic Effect of Furosemide after Single Intravenous, Oral Tablet, and Newly Developed Oral Disintegrating Film Administration in Healthy Beagle Dogs}

\section{Suk-kyu Koh}

Chungnam National University

Jong-Woo Jeong

Chungnam National University

\section{Seo-In Choi}

Chungnam National University

Rae-Man Kim

Inje University

Tae-Sung Koo

Chungnam National University

Kwang-Hyung Cho

Inje University

Kyoung-Won Seo ( $\sim$ kwseo@snu.ac.kr)

Seoul National University

\section{Research Article}

Keywords: Canine, Furosemide, Loop diuretic, Oral film, Tablet, Conventional administration, Congestive heart failure, Diuresis, Noncompliance

Posted Date: April 19th, 2021

DOI: https://doi.org/10.21203/rs.3.rs-403597/v1

License: (c) (i) This work is licensed under a Creative Commons Attribution 4.0 International License. Read Full License 


\section{Abstract}

Background: Furosemide, a diuretic that acts on the loop of Henle, is commonly used to treat congestive heart failure in veterinary medicine. Some owners have difficulty in administering oral tablet medication to animal patients, which leads to noncompliance, especially during long-term administration. The oral disintegrating film (ODF) has the advantages of easy administration via a non-invasive route, rapid dissolution, and low suffocating risk. The objective of this study was to research the pharmacokinetic and pharmacodynamics (PK/PD) profiles of furosemide after intravenous (IV), orally uncoated tablet (OUT), and newly developed ODF administration in healthy beagle dogs. In this study, a furosemideloaded ODF (FS-ODF) formulation was developed and five beagle dogs were administered a single dose $(2 \mathrm{mg} / \mathrm{kg}$ ) of furosemide via each route using a cross-over design.

Results: The most suitable film-forming agent was sodium alginate; thus, this was used to develop an ODF for easy drug administration. No significant differences were detected in the PK profiles between OUT and FS-ODF. The maximum plasma concentration of furosemide was higher and the elimination half-life and time at maximum concentration were slightly lower after FS-ODF administration than after OUT administration. In the blood profiles, the concentration of total protein was significantly increased compared to the baseline $(0 \mathrm{~h})$, whereas no significant difference was detected in the concentration of creatinine and hematocrit compared to the baseline. FS-ODF resulted in a similar hourly urinary output to OUT during the initial $2 \mathrm{~h}$ after administration. The urine specific gravity was significantly decreased compared to the baseline in each group. The peak times of urine electrolyte (sodium and chloride) excretion per hour were $1 \mathrm{~h}$ (IV), $2 \mathrm{~h}$ (OUT), and $2 \mathrm{~h}$ (FS-ODF).

Conclusions: These results suggest that the PK/PD of furosemide after administration of newly developed FS-ODF are similar to those of OUT in healthy dogs. Therefore, the ODF formulation has the benefits of ease and convenience, which would be helpful to owners of companion animals, such as small dogs $(<10 \mathrm{~kg})$ or cats, for the management of congestive heart failure.

\section{Background}

Furosemide, a diuretic commonly used in veterinary and human medicine, is recommended as first-line therapy in the management of congestive heart failure (CHF) $(1,2)$. It is used in animals for the treatment of pulmonary edema, udder edema, hypercalciuric nephropathy, uremia, and hypertension. Additionally, it reduces the incidence of sterile hemorrhagic cystitis associated with cyclophosphamide administration in dogs and is used as adjunctive therapy in hyperkalemia (2-10). The PK/PD properties of loop diuretics, including furosemide after IV and PO administration, have been well investigated in both human and veterinary medicine $(5,8,11-14)$.

Furosemide decreases the absorption of electrolytes in the luminal surface of the thick ascending loop of Henle via the deactivation of the $\mathrm{Na}^{+}-\mathrm{K}^{+}-2 \mathrm{Cl}^{-}$cotransporter. Thus, this drug increases the renal excretion of sodium, potassium, chloride, and water (8). Additionally, furosemide causes renal venodilation, 
increases glomerular filtration rate, increases renal blood flow, and decreases peripheral resistance. Furthermore, furosemide activates the renin-angiotensin-aldosterone-system and sympathetic nervous system (15-17). Although furosemide increases renin secretion, owing to its effects on the nephron, increases in sodium and water retention do not occur (8).

The conventional routes of furosemide administration are intravenous (IV), intramuscular (IM), subcutaneous (SC), or oral (PO). Unless an acute heart failure event occurs, PO administration is indicated in most cases that require long-term use in stable patients $(8,9,18)$. The onset time (IV, $5 \mathrm{~min})$, elimination half-life (IV, 1-1.5 h), duration (IV, 3-6 h), and peak urine output (IV and SC, 1 h; PO, 2 h) of furosemide have been shown in previous experiments in dogs (8).

However, some owners have difficulty administering oral tablet medications, which leads to noncompliance, especially with drugs that require long-term administration. Particularly with cats, it is often difficult to administer pills or capsules. Beyond the conventional administration routes and formulations, studies have been conducted to identify options with similar efficacy that can be easily administered. For human cardiac disease, these studies have led to the development of the sildenafil citrate sublingual tablet to treat pulmonary arterial hypertension, nitroglycerin ointment to treat $\mathrm{CHF}$, transdermal tulobuterol patch for bronchodilation, and transdermal beta-blocker (bisoprolol) patch to reduce postoperative atrial fibrillation (19-22).

The oral disintegrating film (ODF) offers several benefits especially in children, including easy administration via a non-invasive route, fast dissolution, and no risk of choking (23), that also can be utilized in veterinary medicine. Moreover, sublingual and oral furosemide administration differ in pharmacokinetic and pharmacodynamic (PK/PD) results in humans (11); the sublingual route may provide therapeutic advantages over the oral route, especially in patients with CHF. In veterinary medicine, there is a study on the diuretic effect of furosemide according to the IV, SC, PO, and constant rate infusion (CRI) routes in dogs (18). The study on furosemide administration using sublingual bioadhesive film showed ex vivo mucoadhesion using the buccal mucosa and permeability using the tongue excised from slaughtered pigs (24). And the alternative route of administration of furosemide have not been reported except for a study that the therapeutic effect of the transdermal application of furosemide to cats is negligible compared to that after oral and IV administration (7). However, there are no announced studies on alternative administration routes in dogs. Despite there is a need for formulations that can be safely administered to and easily absorbed by animals, ODFs for use in dogs (especially small dogs) and cats have not been developed.

The purpose of this study was to compare the PKs and diuretic effect of furosemide after newly developed furosemide-loaded ODF (FS-ODF), conventional oral commercial tablet, and IV administration.

The first objective of this study was to develop a suitable film applicable containing furosemide, which provide advantages over conventional administration routes in veterinary medicine. The second objective of this study was to compare the PKs and diuretic effect of furosemide after newly developed furosemide-loaded ODF (FS-ODF), conventional oral commercial tablet, and IV administration. We 
hypothesized that the newly developed FS-ODF would have similar drug when compared to oral tablets of the same dose.

\section{Results}

Based on previous studies, film-forming agent and other excipients, including the plasticizer, solubilizer, disintegrant, sweetener, and solvent, were investigated for the most suitable agent and sodium alginate was selected to form the ODF.

Table 1

Formulation of FS-ODF.

\begin{tabular}{|lll|}
\hline Purpose of use & Formulation $(\mathrm{mg})$ & \\
\hline Acitive ingredient & Furosemide & 20 \\
\hline Film forming agent & Sodium alginate & 14 \\
\hline Plasticizer & Glycerin & 4 \\
\cline { 2 - 3 } & PEG 400 & 4 \\
\hline Solubilizer & Tween 80 & 1 \\
\hline Sweetener & D-Sorbitol & 1 \\
\hline Disintegrant & Crospovidone & 6 \\
\hline Total weight $(\mathrm{mg})$ & & 50 \\
\hline
\end{tabular}

The FS-ODF was prepared using the formulation shown in Table 1. Each FS-ODF had a size of $2 \times 3 \mathrm{~cm}^{2}$ and weight of each film is $50 \mathrm{mg}$. This film had a homogeneous surface with some turbidity (Fig. 1). The mean weight of the film and drug content were $51.75 \pm 2.25 \mathrm{mg}$ and $97.63 \% \pm 1.87 \%$, respectively (Table 2). The disintegration time was $33.5 \pm 4.5 \mathrm{~s}$ in water and the bending count, which represents tensile strength, was $4.4 \pm 0.5$.

Table 2

Characterization of FS-ODF.

\begin{tabular}{|ll|}
\hline Film properties & FS-ODF \\
\hline Weight $(\mathrm{mg})$ & $51.75 \pm 2.25$ \\
\hline Drug Content (\%) & $97.63 \pm 1.87$ \\
\hline Disintegration Time (s) & $33.5 \pm 4.5$ \\
\hline Bending Count & $4.4 \pm 0.5$ \\
\hline Results are presented as mean \pm SD $(n=5)$ \\
\hline
\end{tabular}


In the dissolution test, FS-ODF showed a pH-dependent curve (Fig. 2). The dissolution rate at pH 4.0 (96.75\%) and $\mathrm{pH} 6.8$ (98.48\%) was higher than that at $\mathrm{pH} 1.2$ (3.54\%) after $60 \mathrm{~min}$. The dissolution rate at $\mathrm{pH} 1.2$ was less than $10 \%$ after 120 min. However, FS-ODF reached complete dissolution of more than $95 \%$ at $\mathrm{pH} 4.0$ and $\mathrm{pH} 6.8$ within $60 \mathrm{~min}$.

Table 3

Pharmacokinetic parameters of furosemide ( $2 \mathrm{mg} / \mathrm{kg}$ ) based on route of administration in beagle dogs.

\begin{tabular}{|c|c|c|c|c|}
\hline $\begin{array}{l}\text { Pharmacokinetic } \\
\text { parameters }\end{array}$ & IV & OUT & FS-ODF & $\begin{array}{l}\text { P } \\
\text { OUT vs. FS- } \\
\text { ODF }\end{array}$ \\
\hline $\mathrm{C}_{\max }(\mu \mathrm{g} / \mathrm{mL})$ & $\begin{array}{l}6.30 \pm 0.78 \\
(6.46)\end{array}$ & $0.61 \pm 0.31(0.69)$ & $0.81 \pm 0.81(0.58)$ & 0.619 \\
\hline $\mathrm{T}_{\max }(\mathrm{h})$ & $0.083(0.083)$ & $1.05 \pm 0.45(1)$ & $0.65 \pm 0.29(0.75)$ & 0.130 \\
\hline $\mathrm{T}_{1 / 2}(\mathrm{~h})$ & $\begin{array}{l}2.07 \pm 0.76 \\
(1.63)\end{array}$ & $3.46 \pm 1.82(2.86)$ & $2.65 \pm 0.77(2.46)$ & 0.602 \\
\hline MRT (h) & $\begin{array}{l}0.90 \pm 0.25 \\
(0.78)\end{array}$ & $4.76 \pm 1.59$ (3.99) & $3.36 \pm 0.77(3.45)$ & 0.128 \\
\hline$A U C_{i n f}(\mu \mathrm{g} \cdot h / m L)$ & $\begin{array}{l}2.74 \pm 0.25 \\
(2.60)\end{array}$ & $1.62 \pm 0.77(1.77)$ & $1.28 \pm 0.70(1.36)$ & 0.493 \\
\hline $\mathrm{AUC}_{\text {last }}(\mu \mathrm{g} \cdot \mathrm{h} / \mathrm{mL})$ & $\begin{array}{l}2.67 \pm 0.26 \\
(2.56)\end{array}$ & $1.27 \pm 0.49(1.53)$ & $1.14 \pm 0.64(1.11)$ & 0.734 \\
\hline$F(\%)$ & 100 & $\begin{array}{l}59.06 \pm 27.95 \\
(64.74)\end{array}$ & $\begin{array}{l}46.91 \pm 25.49 \\
(50.01)\end{array}$ & 0.493 \\
\hline \multicolumn{5}{|c|}{ 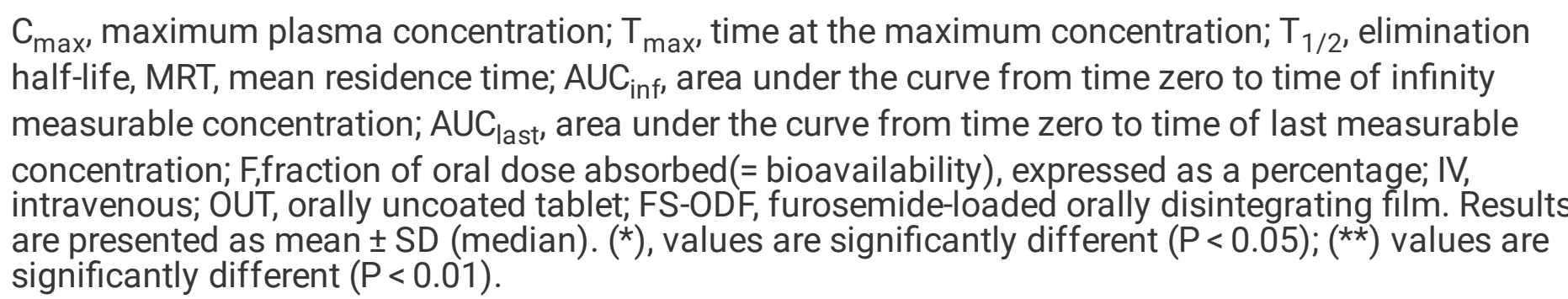 } \\
\hline
\end{tabular}

The dose of furosemide via all three routes was well-tolerated in all dogs. The vital signs on physical examination and behavior did not change during the study period.

PK data of furosemide after the three routes of administration are summarized in Table 3 and presented in Fig. 3. No significant differences were detected between the orally uncoated tablet (OUT) and FS-ODF. In our study, the PK results of plasma furosemide showed a mean $C_{\max }$ of $6.3 \mu \mathrm{g} / \mathrm{mL}$ (IV), $0.61 \mu \mathrm{g} / \mathrm{mL}$ (OUT), and $0.81 \mu \mathrm{g} / \mathrm{mL}$ (FS-ODF), mean AUC last of $2.67 \mu \mathrm{g} \cdot \mathrm{h} / \mathrm{mL}$ (IV), $1.27 \mu \mathrm{g} \cdot \mathrm{h} / \mathrm{mL}$ (OUT), and 1.14 
$\mu \mathrm{g} \cdot \mathrm{h} / \mathrm{mL}$ (FS-ODF), and mean $\mathrm{T}_{1 / 2}$ of $2.07 \mathrm{~h}$ (IV), $3.46 \mathrm{~h}$ (OUT), and $2.65 \mathrm{~h}$ (FS-ODF). A higher maximum plasma concentration $\left(C_{\text {max }}\right)$ and lower elimination half-life $\left(T_{1 / 2}\right)$ of furosemide were observed when administered via the IV route than when administered via the OUT and FS-ODF routes. After FS-ODF administration, the $\mathrm{C}_{\max }$ of furosemide was $33 \%$ higher, whereas the area under the curve from time zero to time of last measurable concentration $\left(A \cup C_{\text {last }}\right)$, time at maximum concentration $\left(T_{\text {max }}\right)$, and $T_{1 / 2}$ were $10 \%, 39 \%$, and $23 \%$ lower, respectively, than those after OUT administration. 
Table 4

Hematocrit and biochemistry profile following single dose of furosemide ( $2 \mathrm{mg} / \mathrm{kg}$ ) administration.

\begin{tabular}{|c|c|c|c|c|c|c|c|}
\hline & & \multirow[t]{2}{*}{ Baseline } & \multicolumn{5}{|l|}{ Time (h) } \\
\hline & & & 1 & 2 & 4 & 6 & 8 \\
\hline \multirow[t]{6}{*}{ Hematocrit(\%) } & \multirow[t]{2}{*}{ IV } & 40.46 & 41.36 & 38.52 & 39.06 & 39.02 & 40.22 \\
\hline & & \pm 9.43 & \pm 5.43 & \pm 6.84 & \pm 7.43 & \pm 6.01 & \pm 5.35 \\
\hline & \multirow[t]{2}{*}{ OUT } & 38.98 & 39.10 & 38.52 & 38.64 & 38.72 & 40.12 \\
\hline & & \pm 4.18 & \pm 3.16 & \pm 3.50 & \pm 3.75 & \pm 4.04 & \pm 3.94 \\
\hline & \multirow{2}{*}{$\begin{array}{l}\text { FS- } \\
\text { ODF }\end{array}$} & 41.94 & 41.02 & 40.20 & 41.44 & 41.58 & 40.54 \\
\hline & & \pm 5.19 & \pm 6.17 & \pm 6.48 & \pm 4.21 & \pm 6.30 & \pm 7.81 \\
\hline \multirow{6}{*}{$\begin{array}{l}\text { BUN } \\
(\mathrm{mg} / \mathrm{dL})\end{array}$} & \multirow[t]{2}{*}{ IV } & 17.10 & 17.50 & 17.20 & 16.72 & 16.20 & 15.94 \\
\hline & & \pm 6.33 & $\pm 5.60^{\star \star}$ & $\pm 5.57^{\star \star}$ & \pm 5.25 & \pm 5.21 & \pm 5.23 \\
\hline & \multirow[t]{2}{*}{ OUT } & 21.84 & 20.82 & 20.22 & 19.04 & 17.52 & 16.60 \\
\hline & & \pm 9.99 & $\pm 9.12^{\star \star}$ & \pm 8.99 & \pm 7.96 & \pm 6.25 & \pm 5.83 \\
\hline & \multirow{2}{*}{$\begin{array}{l}\text { FS- } \\
\text { ODF }\end{array}$} & 18.96 & 18.68 & 18.16 & 17.30 & 16.14 & 15.41 \\
\hline & & \pm 6.39 & $\pm 6.15^{\star \star}$ & \pm 6.10 & $\pm 5.90^{\star \star}$ & $\pm 5.28^{*}$ & $\pm 4.72^{*}$ \\
\hline \multirow{3}{*}{$\begin{array}{l}\mathrm{Cr} \\
(\mathrm{mg} / \mathrm{dL})\end{array}$} & IV & $\begin{array}{l}0.72 \pm \\
0.24\end{array}$ & $\begin{array}{l}0.68 \pm \\
0.19\end{array}$ & $\begin{array}{l}0.68 \pm \\
0.24\end{array}$ & $\begin{array}{l}0.68 \pm \\
0.19\end{array}$ & $\begin{array}{l}0.72 \pm \\
0.13\end{array}$ & $\begin{array}{l}0.68 \pm \\
0.23\end{array}$ \\
\hline & OUT & $\begin{array}{l}0.72 \pm \\
0.29\end{array}$ & $\begin{array}{l}0.70 \pm \\
0.25\end{array}$ & $\begin{array}{l}0.68 \pm \\
0.23\end{array}$ & $\begin{array}{l}0.66 \pm \\
0.23\end{array}$ & $\begin{array}{l}0.68 \pm \\
0.16\end{array}$ & $\begin{array}{l}0.66 \pm \\
0.18\end{array}$ \\
\hline & $\begin{array}{l}\text { FS- } \\
\text { ODF }\end{array}$ & $\begin{array}{l}0.72 \pm \\
0.13\end{array}$ & $\begin{array}{l}0.74 \pm \\
0.19\end{array}$ & $\begin{array}{l}0.68 \pm \\
0.22\end{array}$ & $\begin{array}{l}0.70 \pm \\
0.19\end{array}$ & $\begin{array}{l}0.72 \pm \\
0.19\end{array}$ & $\begin{array}{l}0.70 \pm \\
0.20\end{array}$ \\
\hline \multirow{6}{*}{$\begin{array}{l}\text { Total } \\
\text { protein } \\
(\mathrm{mg} / \mathrm{dL})\end{array}$} & \multirow[t]{2}{*}{ IV } & 5.90 & 6.32 & 6.18 & 6.10 & 6.04 & 6.04 \\
\hline & & \pm 0.36 & $\pm 0.29 \star \star$ & $\pm 0.36^{\star \star}$ & $\pm 0.30 *$ & \pm 0.25 & $\pm 0.34^{\star}$ \\
\hline & \multirow[t]{2}{*}{ OUT } & 5.74 & 6.02 & 6.10 & 6.10 & 5.94 & 6.00 \\
\hline & & \pm 0.29 & $\pm 0.25^{\star \star}$ & $\pm 0.38 * \star$ & \pm 0.31 * & \pm 0.34 & $\pm 0.29 \star$ \\
\hline & \multirow{2}{*}{$\begin{array}{l}\text { FS- } \\
\text { ODF }\end{array}$} & 6.06 & 6.30 & 6.38 & 6.26 & 6.30 & 6.34 \\
\hline & & \pm 0.18 & \pm 0.10 ** & $\pm 0.18^{\star *}$ & $\pm 0.17 *$ & \pm 0.20 & $\pm 0.05^{\star}$ \\
\hline
\end{tabular}


The plasma concentration of total protein was significantly increased $4 \mathrm{~h}$ after IV, 1-4 h after OUT, and 2-4 $\mathrm{h}$ after FS-ODF administration compared to the baseline. However, the plasma blood urea nitrogen (BUN) concentration was significantly decreased $1-2 \mathrm{~h}$ after IV and $4-8 \mathrm{~h}$ after FS-ODF administration compared to the baseline. The plasma concentrations of creatinine and hematocrit were not significantly different compared to the baseline at any time point (Table 4). Moreover, the serum potassium concentration was significantly decreased $1-6 \mathrm{~h}$ after IV and OUT and $1-8 \mathrm{~h}$ after FS-ODF administration, and the serum chloride concentration was significantly decreased $2 \mathrm{~h}$ after IV and OUT administration. Compared to that at the baseline, the serum sodium concentration did not change significantly over time (Table 5). Additionally, the indirect systolic blood pressure was not different among application routes nor time points. 
Table 5

Serum electrolyte concentration following furosemide $(2 \mathrm{mg} / \mathrm{kg})$ administration.

\begin{tabular}{|c|c|c|c|c|c|c|c|}
\hline & & Baseline & Time (h) & & & & \\
\hline & & & 1 & 2 & 4 & 6 & 8 \\
\hline Serum & IV & 151.26 & 148.14 & 148.04 & 150.60 & 147.74 & 148.52 \\
\hline sodium & & \pm 4.06 & \pm 1.46 & \pm 1.13 & \pm 2.10 & \pm 4.79 & \pm 1.30 \\
\hline excretion & OUT & 150.34 & 153.56 & 150.14 & 149.12 & 151.92 & 149.84 \\
\hline$(\mathrm{mmol})$ & & \pm 2.62 & \pm 7.59 & \pm 1.48 & \pm 1.08 & \pm 5.29 & \pm 1.44 \\
\hline & FS-ODF & 150.94 & 155.20 & 150.06 & 148.98 & 153.46 & 148.56 \\
\hline & & \pm 2.97 & \pm 9.26 & \pm 2.12 & \pm 6.06 & \pm 9.29 & \pm 1.09 \\
\hline Serum & IV & 4.48 & 4.19 & 3.97 & 4.12 & 4.04 & 4.15 \\
\hline potassium & & \pm 0.15 & $\pm 0.17^{\star}$ & $\pm 0.29^{\star \star}$ & $\pm 0.29^{\star \star}$ & $\pm 0.31^{\star \star}$ & \pm 0.42 \\
\hline excretion (mmol) & OUT & 4.51 & 4.43 & 3.97 & 4.05 & 4.04 & 4.05 \\
\hline & & \pm 0.34 & $\pm 0.41^{*}$ & $\pm 0.14^{\star *}$ & $\pm 0.23^{\star *}$ & $\pm 0.28^{\star *}$ & \pm 0.27 \\
\hline & FS-ODF & 4.43 & 4.08 & 3.92 & 4.09 & 4.13 & 4.05 \\
\hline & & \pm 0.32 & $\pm 0.36^{* \star}$ & $\pm 0.28^{\star \star}$ & $\pm 0.37^{\star \star}$ & $\pm 0.41^{*}$ & $\pm 0.23^{*}$ \\
\hline Serum & IV & 110.66 & 106.46 & 105.96 & 107.64 & 104.34 & 106.36 \\
\hline chloride & & \pm 4.20 & \pm 1.41 & $\pm 1.33^{*}$ & \pm 2.01 & \pm 4.25 & \pm 0.80 \\
\hline excretion (mmol) & OUT & 110.28 & 111.56 & 107.52 & 105.88 & 107.76 & 106.50 \\
\hline & & \pm 3.38 & \pm 8.26 & $\pm 1.61^{*}$ & \pm 0.58 & \pm 3.43 & \pm 1.35 \\
\hline & FS-ODF & 110.22 & 112.74 & 106.84 & 106.04 & 109.96 & 106.20 \\
\hline & & \pm 3.30 & \pm 7.69 & \pm 1.82 & \pm 4.56 & \pm 7.89 & \pm 1.08 \\
\hline $\begin{array}{l}\text { Results are prese } \\
\text { loaded orally disi } \\
\text { compared to the }\end{array}$ & $\begin{array}{l}\text { s mea } \\
\text { ting fi } \\
\text { ne. }\end{array}$ & $\begin{array}{l}\text { D. IV, int } \\
\text { he p-val }\end{array}$ & $\begin{array}{l}\text { hous; } \\
\text { hre sia }\end{array}$ & $\begin{array}{l}\text { rally ur } \\
\text { ntly dif }\end{array}$ & $\begin{array}{l}\text { ted tab } \\
\text { it }(* p<<\end{array}$ & $\begin{array}{l}\text { S-ODF, } \\
\star \star \mathrm{p}<<0\end{array}$ & semide- \\
\hline
\end{tabular}

The hourly urine output (HUO) and accumulated urinary output are shown in Table 6. The HUO was increased significantly compared to the baseline in each group. The HUO peak of IV administration was high and early, whereas that of OUT and FS-ODF administration was broader and appeared later. The HUO was increased $1 \mathrm{~h}$ after IV administration, then returned to the baseline level after $4 \mathrm{~h}$. The HUO for OUT and FS-ODF was increased 1-2 h after administration and returned to the baseline level after $6 \mathrm{~h}$. The mean duration of diuresis until the return to baseline levels after IV, OUT, and FS-ODF administration 
was $4.1 \mathrm{~h}, 5.72 \mathrm{~h}$, and $5.24 \mathrm{~h}$, respectively. Similar value of HUO were observed between OUT and FS-ODF during the initial $2 \mathrm{~h}$ after administration. The total urine output was $24.65 \mathrm{~mL} / \mathrm{kg}, 30.9 \mathrm{~mL} / \mathrm{kg}$, and 25.4 $\mathrm{mL} / \mathrm{kg}$ during $8 \mathrm{~h}$ after IV, OUT, and FS-ODF administration, respectively. The urine-specific gravity (USG) and urine electrolyte excretion per hour (UEEH) are shown in Table 7. The USG was significantly decreased after administration in all groups but returned to the baseline after $8 \mathrm{~h}$. The UEEH was significantly increased $1-2 \mathrm{~h}$ after administration in all groups. The peak times of sodium and chloride UEEH were $1 \mathrm{~h}, 2 \mathrm{~h}$, and $2 \mathrm{~h}$, whereas those of potassium UEEH were $1 \mathrm{~h}, 1 \mathrm{~h}$, and $2 \mathrm{~h}$, after IV, OUT, and FS-ODF administration, respectively.

Table 6

Hourly urine output and cumulative urine output after furosemide administration via different routes.

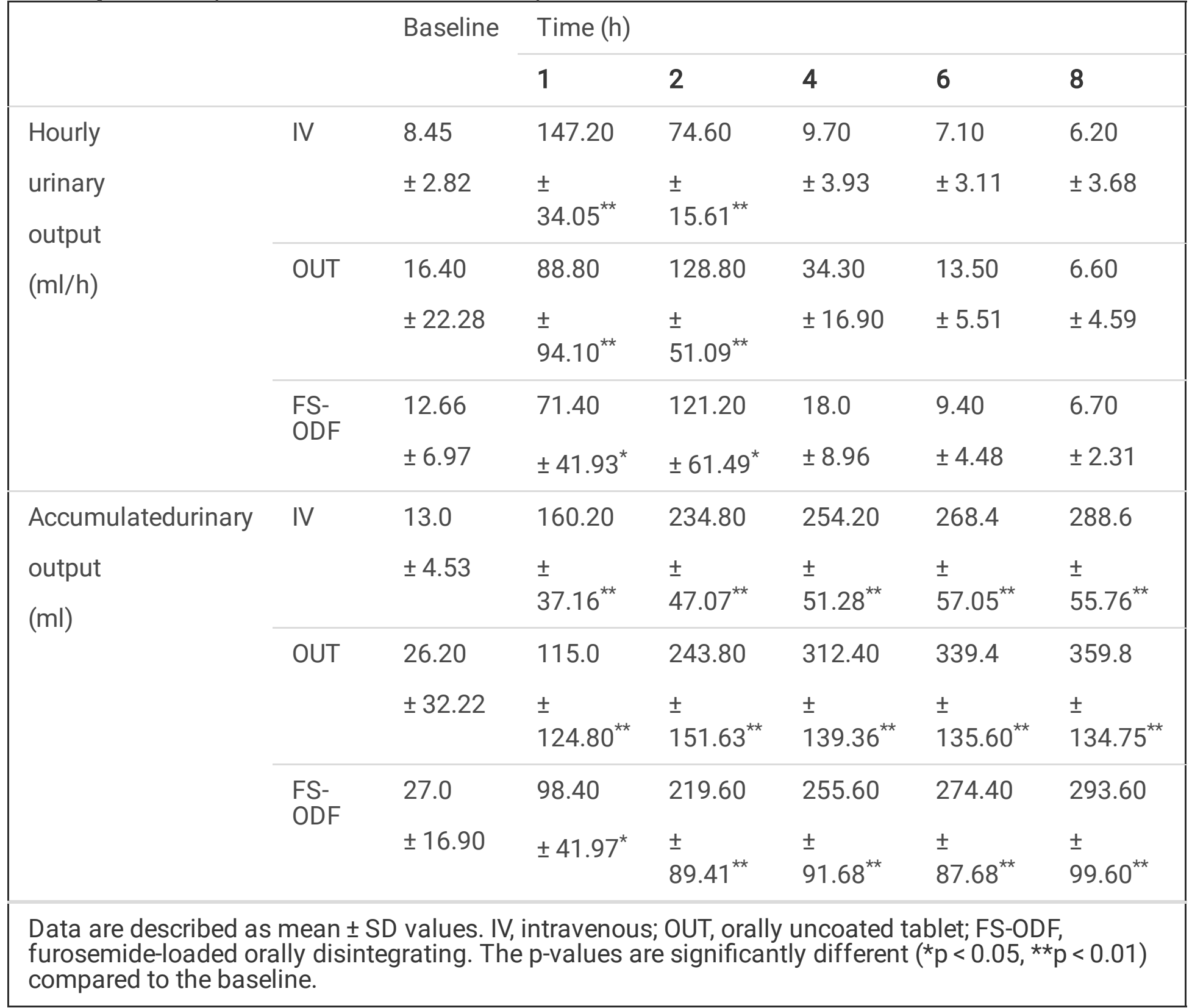


Table 7

Urine-specific gravity and urine electrolyte excretion after furosemide $(2 \mathrm{mg} / \mathrm{kg})$ administration.

\begin{tabular}{|c|c|c|c|c|c|c|c|}
\hline & & Baseline & Time $(\mathrm{h}$ & & & & \\
\hline & & & 1 & 2 & 4 & 6 & 8 \\
\hline Urine-specific & IV & $1.040 \pm$ & 1.012 & 1.007 & 1.011 & $\begin{array}{l}1.020 \\
+\end{array}$ & 1.030 \\
\hline gravity & & 0.010 & $0.002^{* *}$ & $0.001^{* *}$ & $0.002^{* *}$ & $0.004^{*}$ & 0.007 \\
\hline & OUT & $1.039 \pm$ & $\begin{array}{l}1.032 \\
\pm\end{array}$ & $\begin{array}{l}1.012 \\
\pm\end{array}$ & $\begin{array}{l}1.010 \\
\pm\end{array}$ & $\begin{array}{l}1.017 \\
\pm\end{array}$ & $\begin{array}{l}1.022 \\
+\end{array}$ \\
\hline & & 0.009 & $0.015^{\star *}$ & $0.006^{\star *}$ & $0.003^{* \star}$ & $0.006^{*}$ & 0.007 \\
\hline & FS- & $1.045 \pm$ & 1.022 & 1.009 & 1.014 & 1.020 & 1.025 \\
\hline & ODF & 0.007 & & & & & \\
\hline & & & $0.013^{n}$ & $0.002^{n}$ & $0.005^{n}$ & $0.010^{\wedge}$ & $0.009^{\circ}$ \\
\hline Urine sodium & IV & $0.64 \pm$ & 17.75 & $8.70 \pm$ & $0.95 \pm$ & $0.52 \pm$ & $0.35 \pm$ \\
\hline excretion per & & 0.56 & & $3.52^{\star \star}$ & 0.47 & 0.21 & 0.21 \\
\hline & & & & & & & \\
\hline & OUT & $0.95 \pm$ & $\begin{array}{l}11.13 \\
+\end{array}$ & $\begin{array}{l}18.88 \\
+\end{array}$ & $3.77 \pm$ & $1.22 \pm$ & $0.44 \pm$ \\
\hline & & 1.05 & & & 1.77 & 0.52 & 0.22 \\
\hline & & & $11.67^{\star \star}$ & $10.01^{\star \star}$ & & & \\
\hline & FS- & $0.93 \pm$ & $8.63 \pm$ & $\begin{array}{l}17.18 \\
+\end{array}$ & $1.96 \pm$ & $0.78 \pm$ & $0.48 \pm$ \\
\hline & ODF & 0.56 & $4.63^{*}$ & & 0.94 & 0.24 & 0.11 \\
\hline Urine potassium excretion & IV & $0.31 \pm$ & $3.51 \pm$ & $1.11 \pm$ & $0.21 \pm$ & $0.16 \pm$ & $0.16 \pm$ \\
\hline per & & 0.16 & $1.17^{\star \star}$ & $0.32^{\star \star}$ & 0.10 & 0.06 & 0.11 \\
\hline & OUT & $0.92 \pm$ & $4.48 \pm$ & $2.46 \pm$ & $0.63 \pm$ & $0.33 \pm$ & $0.14 \pm$ \\
\hline & & 1.12 & $4.48^{\star \star}$ & $1.24^{\star \star}$ & 0.26 & 0.18 & 0.06 \\
\hline & FS- & $0.79 \pm$ & $2.40 \pm$ & $2.70 \pm$ & $0.41 \pm$ & $0.24 \pm$ & $0.16 \pm$ \\
\hline & ODF & 0.53 & $0.67^{*}$ & $1.38^{\star}$ & 0.21 & 0.13 & 0.06 \\
\hline
\end{tabular}

Data are described as mean \pm SD values. IV, intravenous; OUT, orally uncoated tablet; FS-ODF, furosemide-loaded orally disintegrating film. The $p$-values are significantly different $\left({ }^{\star} p<0.05,{ }^{*} p<\right.$ 0.01) compared to the baseline. 


\begin{tabular}{|c|c|c|c|c|c|c|c|}
\hline \multirow[t]{4}{*}{$\begin{array}{l}\text { Urine chloride } \\
\text { excretion per } \\
\text { hour }(\mathrm{mmol} / \mathrm{h})\end{array}$} & IV & 0.11 & $\begin{array}{l}11.43 \\
\pm \\
3.04^{\star *}\end{array}$ & $\begin{array}{l}5.72 \pm \\
1.33^{\text {** }}\end{array}$ & $\begin{array}{l}0.72 \pm \\
0.33\end{array}$ & $\begin{array}{l}0.32 \pm \\
0.12\end{array}$ & $\begin{array}{l}0.19 \pm \\
0.08^{\star \star}\end{array}$ \\
\hline & OUT & $\begin{array}{l}1.04 \pm \\
1.29\end{array}$ & $\begin{array}{l}8.48 \pm \\
9.14^{\text {** }}\end{array}$ & $\begin{array}{l}10.29 \\
\pm \\
4.41^{\star \star}\end{array}$ & $\begin{array}{l}2.63 \pm \\
1.36\end{array}$ & $\begin{array}{l}0.84 \pm \\
0.38\end{array}$ & $\begin{array}{l}0.25 \pm \\
0.09^{* \star}\end{array}$ \\
\hline & FS- & $0.76 \pm$ & $4.89 \pm$ & $9.60 \pm$ & $1.39 \pm$ & $0.53 \pm$ & $0.30 \pm$ \\
\hline & ODF & 0.47 & $2.62^{*}$ & $5.21^{\star}$ & 0.62 & 0.23 & 0.09 \\
\hline
\end{tabular}

\section{Discussion}

To the authors' knowledge, this study is the first to compare the PK/PD parameters of IV, OUT and ODF administration of furosemide in dogs. Among the conventional routes of furosemide administration, PO administration is the most common route for long-term management in veterinary patients with CHF (8, 9). However, in the case of home care, oral tablet administration may be limited by low patient cooperation and it is difficult to use other traditional administration routes, such as IM, SC, and IV. For this reason, we did research into alternative routes that could actually be applied to veterinary medicine.

Usually, ODFs disintegrate within 1 min in the oral cavity owing to contact with the saliva, which results in rapid absorption and drug bioavailability. Furthermore, when administered via buccal or sublingual routes, there are advantages of high permeability and bypassing first-pass metabolism (23). In this study, the ODF dissolved in the mouths of dogs quickly without water, which indicates that the ODF formulation is beneficial with regard to rapid dissolution, absorption, and ease of drug administration in veterinary patients. Therefore, a low-dose FS-ODF formulation for small animals was developed.

Based on our research results, sodium alginate decided to use as film-forming agent containing furosemide. Then, $20 \mathrm{mg}$ of furosemide (a high ratio; $40 \%$, w/w) was loaded per sheet, which was cut depending on the body weight of the dog to reach a dose of $2 \mathrm{mg} / \mathrm{kg}$. These physical specifications were achieved for convenience of use in small animals, such as small dogs $(<10 \mathrm{~kg})$ or cats $(25)$. The small and uniform particles of furosemide in the final preparation suspension enabled the homogeneous and desirable film surface and might have reduced weight variation and content loss (26). The formulation was optimized, with a disintegration time of less than $40 \mathrm{~s}$, owing to the presence of crospovidone as a disintegrant. Rapid disintegration to small particles in the mouth is an essential property to ensure the good usability of a film (27). Moreover, the bending count was in an acceptable range and showed the flexibility of the film. Overall, FS-ODF had suitable film properties in terms of appearance, drug content, disintegration time, and tensile strength. 
In the dissolution test, FS-ODF showed a pH-dependent curve because furosemide has a highly $\mathrm{pH}$ dependent solubility. Furosemide is a weak acid $(\mathrm{pKa}=3.48)$ with a carboxylic acid functional group and its aqueous solubility increases as the $\mathrm{pH}$ increases from $0.18 \mathrm{mg} / \mathrm{mL}(\mathrm{pH} 2.3)$ to $13.36 \mathrm{mg} / \mathrm{mL}(\mathrm{pH}$ 10.0) (28). Thus, in this study, the dissolution rate was in the order of $\mathrm{pH} 6.8>\mathrm{pH} 4.0>>\mathrm{pH} 1.2$ within 60 min. FS-ODF showed immediate-release on the curve (Fig. 2), with high dissolution rates at pH 4.0 and pH 6.8 owing to the rapid disintegration time of less than $1 \mathrm{~min}$. Therefore, FS-ODF was sufficient, in terms of disintegration time and dissolution rate, for administration to small animals.

In dogs and humans, the diuretic effect caused by furosemide continues for $3 \mathrm{~h}$ after IV injection. The concentration of furosemide initially exceeds the number of $\mathrm{Na}^{+}-\mathrm{K}^{+}-2 \mathrm{Cl}^{-}$cotransporters in the loop of Henle after IV administration and are excreted in the urine. Thereafter, the furosemide concentration declines under therapeutic concentrations (29-31).

Additionally, the bioavailability of furosemide is different depending on the administration method. For example, when administered orally, the first-pass effect, related to the extent of gastrointestinal absorption and metabolism, plays a major role in the bioavailability of furosemide. Also, the first-pass effect varies by species and individual. The diuretic effect of furosemide after PO administration has a slower onset than that after IV and SC administration (32). Furthermore, the bioavailability of furosemide is approximately $77 \%$ in dogs and $60-65 \%$ in humans after PO administration $(8,13,29)$. The bioavailability of furosemide after IV administration is greater than that after PO administration, and the diuretic effect continues 1-2 $\mathrm{h}$ after IV injection. Moreover, the absorption of furosemide is influenced by the $\mathrm{pH}$ and the existence of binding proteins in the stomach $(18,33,34)$. Although furosemide is slowly absorbed in the small intestine, it is absorbed rapidly in the stomach because of the acid environment. The absorption of furosemide in the gastrointestinal tract of patients with CHF may be lower than normal (35). Generally, in patients with CHF, absorption delay may be the result of increased motility, reduced perfusion, or mucosal edema of intestine $(36,37)$.

The PKs of furosemide determine the therapeutic effect, entry rate of drug into the blood and urine, and onset and duration of effects, all of which are altered by the method of administration $(18,29,30)$. Both OUT and FS-ODF administration showed a slower onset and a longer elimination half-life than IV administration. Previous studies have shown a half-life of $0.5-1 \mathrm{~h}$ after IV administration, whereas the half-life has been reported as $30 \mathrm{~min}$ in the major disposition phase and approximately $7 \mathrm{~h}$ in the slow elimination phase after $\mathrm{PO}$ administration in dogs $(5,6,38)$. According to another PK/PD study in healthy beagle dogs, the half-life after $\mathrm{PO}$ administration in dogs is $3 \mathrm{~h}$, which is similar to the results of the present study (39).

In the body, furosemide moves across the renal tubule from the plasma to the lumen of the nephron; thus, furosemide acting on henle's loop of renal tubule should have a short duration of effects if its half-life is short (7). After IV administration, the $\mathrm{C}_{\max }$ was slightly higher than that after OUT or FS-ODF administration, whereas the $T_{1 / 2}$ and $T_{\max }$ were slightly lower. These results appear to be owing to the initial high blood concentration and rapid elimination of furosemide after IV administration. In addition to 
the route of administration of the drug, it should also be considered that the half-life of drugs is affected by many factors, including illness status, age, and other physiological variables (40). The present study demonstrates that the PKs after the administration of FS-ODF are similar to those after that of OUT in healthy dogs.

Furthermore, after IV administration, the HUO was significantly increased and peaked after $1 \mathrm{~h}$, then decreased gradually to baseline levels. This result was similar to the predicted PK result of the IV route (8). The HUO of OUT and FS-ODF routes were significantly increased after $1-2 \mathrm{~h}$ and peaked after $2 \mathrm{~h}$. Therefore, FS-ODF and OUT resulted in a similar HUO during the initial $2 \mathrm{~h}$ after administration

The duration of diuresis (time until return to baseline level after furosemide administration) after OUT and FS-ODF administration was similar at $5 \mathrm{~h}$. Additionally, UEEHs were increased during the initial $2 \mathrm{~h}$ after administration in all groups. Based on HUO, USG, and UEEH results, FS-ODF has equivalent aquaretic, natriuretic, kaliuretic, chloriuretic, and diuretic effects to conventional OUT.

This study has a few limitations, which may be overcome by further research. First, additional studies using different doses and repeating doses are needed because we used only a single dose of furosemide ( $2 \mathrm{mg} / \mathrm{kg}$ ). Second, we only used five healthy intact beagle dogs. Additional studies should be conducted in more dog patients with CHF, renal failure, and delayed intestinal absorption. Third, there is a need to study the administration of this drug by ODF in various animals, including cats.

\section{Conclusion}

In this study, we developed an ODF for small animals that showed similar PK/PD results to OUT administration. Collectively, the results of this study suggest that the FS-ODF formulation can be used as an alternative to oral tablets in animal patients with heart failure and volume overload. Therefore, it would be helpful to owners of small dogs and cats that refuse conventional oral medications owing to the potential benefits of easy administration and convenient dosage form.

\section{Methods}

\section{Animals}

Five clinically healthy adult beagle dogs (three intact males and two intact females) dogs from a research colony at the College of Veterinary Medicine of Chungnam National University were included in this study. The animals were 5-9 years of age and weighed $10-13 \mathrm{~kg}$. All dogs were normal on physical examination, including systemic blood pressure measurement with a Doppler device, and within normal ranges on complete blood count, serum biochemistry panel, serum electrolytes, and urinalysis. Animals were housed in cages and fed commercial food (SUNGBO Pet Healthcare, Seoul, South Korea) twice daily. Water was provided ad libitum. This study was approved by the Institutional Animal Care and Use Committee (IACUC) at Chungnam National University (approval number, CNU-01189). After the study, all dogs were adopted as companion animals. 


\section{Preparation of FS-ODF}

The FS-ODFs were prepared by a simple, easy solvent-casting method that required no special equipment (41). For lab-scale preparation, as the batch size was 15 FS-ODFs, the amount of formulation for 15 FSODFs was weighed and used (Table 1). Furosemide and two plasticizers were dissolved in $4.5 \mathrm{~mL}$ of ethanol, heated in $80^{\circ} \mathrm{C}$ chambers for $30 \mathrm{~min}$. This solution was transferred to a $40{ }^{\circ} \mathrm{C}$ chamber to reach temperature equilibrium (Solution A). The other excipients, including the film-forming agent, solubilizer, and sweetener, were dissolved in $10.5 \mathrm{~mL}$ of water and the disintegrant was suspended. This aqueous solution was transferred to $40^{\circ} \mathrm{C}$ chambers to reach temperature equilibrium (Solution B). Solution $\mathrm{A}$ was added to Solution B and the mixture was stirred at room temperature $\left(22-24{ }^{\circ} \mathrm{C}\right)$ for 30 min to obtain a uniform suspension. This suspension was sonicated for $10 \mathrm{~min}$ for degassing. The amount of suspension equivalent to 10.60 films on an area basis was placed on a Petri dish (9 $\mathrm{cm}$ in diameter) and dried in $80^{\circ} \mathrm{C}$ chambers for $40-45 \mathrm{~min}$. The formed film was peeled off and cut to a predetermined size of $2 \times 3 \mathrm{~cm}^{2}$.

\section{Characterization of FS-ODF}

\section{Disintegration Time}

One FS-ODF was placed on a petridish ( $9 \mathrm{~cm}$ diameter) with $15 \mathrm{~mL}$ of $37^{\circ} \mathrm{C}$ water. The time to disintegrate completely was measured by visual observation (42). The absence of any significant floating fragments was considered to be the completion of disintegration.

\section{Bending Count}

The bending count measured by the number of times it took to split when the film was folded in half repeatedly with two fingers.

\section{Weight and Drug Content}

The prepared FS-ODF was weighed using balance and transferred into $30 \mathrm{~mL}$ dilution solution $(0.05 \mathrm{~N}$ $\mathrm{NaOH}$ solution) in $50 \mathrm{~mL}$ volumetric flask and dissolved with vortexing. Then, the dilution solution was added to be total volume. This solution of $2 \mathrm{~mL}$ was transferred to $100 \mathrm{~mL}$ volumetric flask and the dilution solution was added to be total volume. The final solution was filtered with syringe filter $(0.45 \nabla)$ and the filtrate was analyzed by the below HPLC method.

\section{HPLC Condition}

The HPLC analysis of furosemide in the samples was conducted using a Waters 2695 HPLC system (Waters, Milford, MA, USA) equipped with a UV-Vis detector (Waters 2487, Waters, Milford, MA, USA). Furosemide was analyzed using the reverse column with C18, $5 \mu \mathrm{m}, 4.5 \mathrm{~mm} \times 25 \mathrm{~cm}$ (Shiseido, Tokyo, Japan). The mobile phase consisted of water, tetrahydrofuran, and acetic acid (70:30:1, v/v/v). The HPLC analysis was performed with a flow rate of $1.2 \mathrm{~mL} / \mathrm{min}$. The injected volume of the sample was $20 \mu \mathrm{L}$, 
and UV detection was monitored at $272 \mathrm{~nm}$ (43). Data acquisition and processing were carried out using the Waters LC Solution software.

\section{Dissolution Test}

The dissolution test was performed using the USP (35) dissolution apparatus II at pH $1.2(0.1 \mathrm{~N} \mathrm{HCl} / \mathrm{NaCl}$ buffer), pH 4.0 (acetate buffer), $\mathrm{pH} 6.8$ (phosphate buffer) with the media volume of $900 \mathrm{~mL}$ at $37.0 \pm 0.5$ ${ }^{\circ} \mathrm{C}$. The rotational speed was adjusted to $50 \mathrm{rpm}$. The prepared FS-ODF containing furosemide $20 \mathrm{mg}$ in a sample was placed into a dissolution vessel with a sinker (44). At each predetermined interval, the aliquot $(5 \mathrm{~mL})$ of the medium was collected and filtered through a membrane filter (pore size: $0.45 \mu \mathrm{m}$ ). The concentration of furosemide in the filtrate was determined using the above HPLC method.

\section{Study design}

This study was performed using a single-dose, randomized, 3-way crossover design. Three methods of furosemide administration were used in each subject with at least 7-day washout period between each experiment. Animals were fasted for 12 hours before the administration of furosemide and had a free access to water during the experiment.

Each (random) animals received a furosemide of $2 \mathrm{mg} / \mathrm{kg}$ via intravenous (IV), orally uncoated tablet (OUT), furosemide-loaded orally disintegrating film (FS-ODF) routes: (1) Furosemide $2 \mathrm{mg} / \mathrm{kg}$ IV, (2) OUT formulation of furosemide $2 \mathrm{mg} / \mathrm{kg}$ orally, (3) FS-ODF formulation $2 \mathrm{mg} / \mathrm{kg}$ orally.

Injections and OUT formulation of furosemide were purchased from handok Pharm. Co. (Seoul, South Korea). For oral administration, furosemide OUT and FS-ODF formulation were cut according to body weight of each dog. Also, 22-Gauge IV catheter was used in the cephalic vein for the IV injections. All dogs were not received other medications before experiment and during the washout period.

\section{Sample collection}

Blood samples were collected at 0 (serving as baseline), 5, 15, 30, 45, 60, 120, 240, 360, 480 minutes in each administration routes. All blood samples were obtained from the jugular vein with 23-Gauge $5 \mathrm{~mL}$ syringe. These samples were immediately divided into heparinized tubes for biochemical test, plain tubes for electrolyte analysis and EDTA-K2 tube for hematocrit. Heparinized plasma and serum were separated after centrifugation at $3,000 \times \mathrm{g}$ for 15 minutes and stored at $-20^{\circ} \mathrm{C}$ until analysis. A complete blood count, BUN, creatinine ( $\mathrm{Cr}$ ), plasma total protein and serum electrolytes were measured.

The urine samples were collected at 0 (serving as baseline), 1, 2, 4, 6, 8 hours in each administration routes. In line with previous studies, the bladder was initially emptied 2 hours before baseline and then collected in 2 hours to calculate baseline hourly urine output (HUO) before furosemide administration. An indwelling 6-8 Fr balloon Foley catheter was placed into the urinary bladder at the initiation of each experiment and the bladder was emptied for urine volume measured at each time point. Urine sample 
was centrifuged ( $1500 \times \mathrm{g}, 10 \mathrm{~min})$ and the supernatant was collected to verify urine-specific gravity and the concentrations of sodium, potassium and chloride.

Complete blood count was measured by ADVIA 2120i (SIEMENS corporation, Munich, Germany) and biochemistry were measured by Mindray BS-300 (Bio-Medical Electronics Co., Ltd, Shenzhen, China). Electrolyte concentrations in plasma and urine sample were measured by EasyLyte PLUS (MEDICA corporation, Bedford, USA).

\section{Quantification of furosemide in plasma}

Plasma concentration of furosemide were determined by HPLC-MS/MS system. To prepare appropriate assay samples, plasma samples were processed with acetonitrile to induce precipitation of plasma protein. More details as follows; firstly, $15 \mu \mathrm{L}$ of plasma or calibrator sample were treated with $155 \mu \mathrm{L}$ of $0.11 \mu \mathrm{g} / \mathrm{mL}$ ibuprofen (internal standard, IS) in acetonitrile. And then, sample mixtures were vigorously shaken by vortex mix for 15 minutes. Finally, sample mixtures were separated into supernatant and precipitant pellet by centrifugation at $17,600 \mathrm{~g}$ for 15 minutes. Standard samples were prepared by spiking of $5 \mu \mathrm{L}$ working solution (as furosemide; $0,30,100,300,1,000,3,000,10,000,30,000$, and 100,000 $\mathrm{ng} / \mathrm{mL}$ in acetonitrile) into $45 \mu \mathrm{L}$ of blank plasma. For a sample analysis, $130 \mu \mathrm{L}$ of supernatant were transferred into sample vials, and $5 \mu \mathrm{L}$ of processed sample was directly injected into HPLC separation system.

Furosemide and IS were separated by Agilent $1100 \mathrm{HPLC}$ system. Chromatographic separation was conducted on Agilent ZORBAX ${ }^{\circledR}$ phase phenyl column $(5 \mu \mathrm{m}, 2.1 \times 50 \mathrm{~mm})$ by $6 \mathrm{mM}$ ammonium formate in $40 \%$ acetonitrile solution.

After a separation, both analytes were detected by triple quadrupole mass spectrometer (AB SCIEX API4000 QTRAP $($ ). Furosemide and IS were monitored under electrospray ionization negative mode as multiple reaction monitoring, which mass to charge ratio of $329.08^{-}$to $284.80^{-}$for furosemide and $205.05^{-}$ to $161.10^{-}$for IS, respectively.

Peak areas integration and quantification were automatically conducted by using Analyst software ${ }^{\circledR}(A B$ Sciex) 1.6.2. Concentration-response of furosemide was linear at ranges from $30 \mathrm{ng} / \mathrm{mL}$ to $10 \mu \mathrm{g} / \mathrm{mL}$.

\section{Pharmacokinetic analysis}

Temporal profiles of furosemide in beagle were analyzed with via non-compartmental model using Phoenix WinNonlin 6.2. (Pharsight, USA). The following pharmacokinetic parameters were calculated and compared based on the route of administration: $C_{\text {max }}$, half-life time, $A U C s, C L, V_{s s}$, bioavailability (BA). The elimination rate constant $\left(\mathrm{k}_{\mathrm{e}}\right)$ was determined by linear regression of the semi-log portion of the elimination phase. The elimination half-life $\left(T_{1 / 2}\right)$ was calculated by dividing 0.693 with $k_{e}$. The area under the plasma concentration versus time curve from time zero to infinity $\left(A \cup C_{\text {inf }}\right)$ and the area under the respective first moment time curve from time zero to infinity $\left(A \cup M C_{\text {inf }}\right)$ were calculated based on the 
linear-trapezoidal method. To estimate the elimination clearance $(\mathrm{CL})$ and volume of distribution at steady state $\left(\mathrm{V}_{\mathrm{ss}}\right)$, a moment analysis was conducted. In more detail, $C L$ was gained by dividing administered dose with $A U C_{\text {inf. }} V_{\text {ss }}$ was obtained by multiply $C L$ with MRT, which division of $A U M C_{\text {inf }}$ by $A U C_{\text {inf. }}$ BAs of film and tablet groups were calculated from the dose normalized $A U C_{P O} / A U C_{I V}$, respectively.

\section{Statistical methods}

All data were expressed as mean and standard deviation values. Normality test was conducted with Kolmogorov-Smirnov test and pharmacokinetic parameters were an independent $t$-test. Because the study aimed to compare orally uncoated tablet with orally disintegrating film, only the differences between these two formulations of administration were statistically analyzed. Comparisons between baseline ( $0 \mathrm{~h})$ and various time phases after drug administration were analyzed statistically using the paired $t$-test. A $P$ value $<0.05$ was considered to be statistically significant. Statistical analysis was performed using SPSS 25 (SPSS Inc., Chicago, IL, USA).

\section{Abbreviations}

IV: Intravenous; CRI: constant-rate infusion; SC: subcutaneous; PO: oral; OUT: orally uncoated tablet; ODF: orally disintegrating film; FS-ODF: furosemide loaded-orally disintegrating film; BUN: blood urea nitrogen; Cr: creatinine; HUO: hourly urine output; PK/PD: pharmacokinetic and pharmacodynamics; PK: pharmacokinetics; HPLC-MS/MS: High-performance liquid chromatography-tandem mass spectrometry; HPLC: High-performance liquid chromatography; $\mathrm{C}_{\max }$ : maximum plasma concentration ; $T_{\max }$ : time at the maximum concentration; $\mathrm{T}_{1 / 2}$ : elimination half-life; $\mathrm{AUC}_{\text {inf: }}$ area under the curve from time zero to time of infinity measurable concentration; $\mathrm{AUC}_{\text {last }}$ : area under the curve from time zero to time of last measurable concentration; F: fraction of oral dose absorbed; MRT: mean residence time; USG: urine specific gravity; UEEH: urinary electrolytes excretion per hour

\section{Declarations}

\section{Ethics approval and consent to participate}

This study was approved by the Institutional Animal Care and Use Committee at Chungnam National University (Approval number: CNU-01189). All methods were carried out in accordance with relevant guidelines and regulations.

\section{Consent for publication}

Not applicable.

\section{Availability of data and materials}


The data for figures, tables, and material used and analyzed during the current study are available from the corresponding author on reasonable request.

\section{Competing interests}

The authors declare that they have no competing interests. The authors declare that the research was conducted in the absence of any commercial or financial relationships that could be construed as a potential conflict of interest.

\section{Funding}

Not applicable.

\section{Authors' contributions}

KSK performed the clinical procedures and data analysis and interpretation and drafted the manuscript.

JWJ performed pharmacokinetic analysis and contributed to statistical analysis.

SIC contributed to scientific discussions and helped clinical procedures.

RMK prepared and characterized FS-ODFs.

TSK participated in the study design and revised the manuscript.

KHJ developed and provided film materials used for study.

KWS were responsible for the study design and academic direction and contributed to revising, editing, and writing of manuscript.

All authors have read and approved the final manuscript.

\section{Acknowledgements}

This manuscript is written based on the Master's thesis of author Suk-Kyu Koh. This research with the support of "Cooperative Research Program of Center for Companion Animal Research (Project No. PJ140452): Rural Development Administration, Republic of Korea.

\section{References}

1. Hori Y, Ohshima N, Kanai K, Hoshi F, Itoh N, Higuchi S. Differences in the duration of diuretic effects and impact on the renin-angiotensin-aldosterone system of furosemide in healthy dogs. $J$ Vet Med Sci. 2010;72(1):13-8.

2. Yancy CW, Jessup M, Bozkurt B, Butler J, Casey DE, Jr., Colvin MM, et al. 2017 ACC/AHA/HFSA Focused Update of the 2013 ACCF/AHA Guideline for the Management of Heart Failure: A Report of 
the American College of Cardiology/American Heart Association Task Force on Clinical Practice Guidelines and the Heart Failure Society of America. Circulation. 2017;136(6):e137-e61.

3. Biddle TL, Yu PN. Effect of furosemide on hemodynamics and lung water in acute pulmonary edema secondary to myocardial infarction. Am J Cardiol. 1979;43(1):86-90.

4. Davidov M, Kakaviatos N, Finnerty FA, Jr. Intravenous administration of furosemide in heart failure. JAMA. 1967;200(10):824-9.

5. Hirai J, Miyazaki H, Taneike T. The Pharmacokinetics and Pharmacodynamics of Furosemide in the Anesthetized Dog. Journal of Veterinary Pharmacology and Therapeutics. 1992;15(3):231-9.

6. Lee MG, Li T, Chiou WL. Effect of intravenous infusion time on the pharmacokinetics and pharmacodynamics of the same total dose of furosemide. Biopharm Drug Dispos. 1986;7(6):537-47.

7. Sleeper MM, O'Donnell P, Fitzgerald C, Papich MG. Pharmacokinetics of furosemide after intravenous, oral and transdermal administration to cats. J Feline Med Surg. 2018:1098612X18805879.

8. Plumb DC. Furosemide, In: Plumb DC. ed. Veterinary Drug Hand-book. 9th ed. . 2018:pp. 726-31.

9. MD. K. Management of heart failure, In: Kittleson MD, Kienle RD. eds. Small Animal Cardiovascular Medicine. St Louis: Mosby. 1998:pp.149-94.

10. GERALD J. YAKATAN DDM, JEAN SCHOLLER, WM. J. NOVICK, Jr., and JAMES T. DOLUISIO. Absorption, Distribution, Metabolism, and Excretion of Furosemide in Dogs and Monkeys I Analytical Methodology, Metabolism, and Urinary Excretion. Journal of Pharmaceutical Sciences. 1976;Vol. 65(No.10):pp.1456-60.

11. Haegeli L, Brunner-La Rocca HP, Wenk M, Pfisterer M, Drewe J, Krahenbuhl S. Sublingual administration of furosemide: new application of an old drug. Br J Clin Pharmacol. 2007;64(6):804-9.

12. Benet LZ. Pharmacokinetics/pharmacodynamics of furosemide in man: a review. J Pharmacokinet Biopharm. 1979;7(1):1-27.

13. El-Sayed MG, Atef M, El-Gendi AY, Youssef SA. Disposition kinetics of furosemide in dogs. Arch Int Pharmacodyn Ther. 1981;253(1):4-10.

14. Miyazaki H, Hirai J, Taneike T. The Pharmacokinetics and Pharmacodynamics of Furosemide in Anesthetized Dogs with Normal and Experimentally Decreased Renal-Function. Japanese Journal of Veterinary Science. 1990;52(2):265-73.

15. Francis GS, Siegel RM, Goldsmith SR, Olivari MT, Levine TB, Cohn JN. Acute vasoconstrictor response to intravenous furosemide in patients with chronic congestive heart failure. Activation of the neurohumoral axis. Ann Intern Med. 1985;103(1):1-6.

16. Hori Y, Katou A, Tsubaki M, Kanai K, Nakao R, Hoshi F, et al. Assessment of diuretic effects and changes in plasma aldosterone concentration following oral administration of a single dose of furosemide or azosemide in healthy dogs. Am J Vet Res. 2008;69(12):1664-9.

17. Tsutsui T, Tsutamoto T, Maeda K, Kinoshita M. Comparison of neurohumoral effects of short-acting and long-acting loop diuretics in patients with chronic congestive heart failure. J Cardiovasc 
Pharmacol. 2001;38 Suppl 1:S81-5.

18. Harada K, Ukai Y, Kanakubo K, Yamano S, Lee J, Kurosawa TA, et al. Comparison of the diuretic effect of furosemide by different methods of administration in healthy dogs. J Vet Emerg Crit Care (San Antonio). 2015;25(3):364-71.

19. Chandraratna PA, Langevin E, O'Dell R, Rubenstein C, San Pedro S. Use of nitroglycerin ointment in congestive heart failure. Results of acute and chronic therapy. Cardiology. 1978;63(6):337-42.

20. Zayed R, Kamel AO, Shukr M, El-Shamy AEH. An in vitro and in vivo comparative study of directly compressed solid dispersions and freeze dried sildenafil citrate sublingual tablets for management of pulmonary arterial hypertension. Acta Pharmaceut. 2012;62(3):411-32.

21. Tamura G, Ichinose M, Fukuchi Y, Miyamoto T. Transdermal Tulobuterol Patch, a Long-Acting beta(2)Agonist. Allergol Int. 2012;61(2):219-29.

22. Okamura $\mathrm{H}$, Arakawa $\mathrm{M}$, Miyagawa $\mathrm{A}$, Adachi $\mathrm{H}$. Incidence of postoperative atrial fibrillation in transdermal beta-blocker patch users is lower than that in oral beta-blocker users after cardiac and/or thoracic aortic surgery. Gen Thorac Cardiovasc Surg. 2019;67(12):1007-13.

23. Karki S, Kim H, Na SJ, Shin D, Jo K, Lee J. Thin films as an emerging platform for drug delivery. Asian J Pharm Sci. 2016;11(5):559-74.

24. De Caro V, Ajovalasit A, Sutera FM, Murgia D, Sabatino MA, Dispenza C. Development and Characterization of an Amorphous Solid Dispersion of Furosemide in the Form of a Sublingual Bioadhesive Film to Enhance Bioavailability. Pharmaceutics. 2017;9(3).

25. Vondrak B, Barnhart S. Dissolvable films: dissolvable films for flexible product format in drug delivery. 2008.

26. Borges AF, Silva C, Coelho JFJ, Simoes S. Oral films: Current status and future perspectives I Galenical development and quality attributes. J Control Release. 2015;206:1-19.

27. Shoukri RA, Ahmed IS, Shamma RN. In vitro and in vivo evaluation of nimesulide lyophilized orally disintegrating tablets. Eur J Pharm Biopharm. 2009;73(1):162-71.

28. Devarakonda B, Otto DP, Judefeind AA, Hill RA, de Villiers MM. Effect of $\mathrm{pH}$ on the solubility and release of furosemide from polyamidoamine (PAMAM) dendrimer complexes. Int J Pharmaceut. 2007;345(1-2):142-53.

29. Branch RA, Roberts CJ, Homeida M, Levine D. Determinants of response to frusemide in normal subjects. Br J Clin Pharmacol. 1977;4(2):121-7.

30. Kaojarern S, Day B, Brater DC. The time course of delivery of furosemide into urine: an independent determinant of overall response. Kidney Int. 1982;22(1):69-74.

31. van Meyel JJ, Smits P, Russel FG, Gerlag PG, Tan Y, Gribnau FW. Diuretic efficiency of furosemide during continuous administration versus bolus injection in healthy volunteers. Clin Pharmacol Ther. 1992;51(4):440-4.

32. Kim EJ, Han KS, Lee MG. Gastrointestinal first-pass effect of furosemide in rats. J Pharm Pharmacol. 2000;52(11):1337-43. 
33. Doungngern T, Huckleberry Y, Bloom JW, Erstad B. Effect of Albumin on Diuretic Response to Furosemide in Patients with Hypoalbuminemia. Am J Crit Care. 2012;21(4):280-6.

34. Farless LB, Steil N, Williams BR, Bailey FA. Intermittent subcutaneous furosemide: parenteral diuretic rescue for hospice patients with congestive heart failure resistant to oral diuretic. Am J Hosp Palliat Care. 2013;30(8):791-2.

35. Ansel HC ALJ, Popovich NG. Pharmaceutical Dosage Forms and Drug Delivery Systems. 7th ed. Philadelphia: Lippin-cott Willams \& Wilkins. 1999:pp. 60-100.

36. Ponto LL, Schoenwald RD. Furosemide (frusemide). A pharmacokinetic/pharmacodynamic review (Part II). Clin Pharmacokinet. 1990;18(6):460-71.

37. Brater DC. Pharmacokinetics of loop diuretics in congestive heart failure. Br Heart J. 1994;72(2 Suppl):S40-3.

38. Yakatan GJ, Maness DD, Scholler J, Johnston JT, Novick WJ, Jr., Doluisio JT. Plasma and tissue levels of furosemide in dogs and monkeys following single and multiple oral doses. Res Commun Chem Pathol Pharmacol. 1979;24(3):465-82.

39. Pelligand L, Guillot E, Geneteau A, Guyonnet J, Magnier R, Elliott J, et al. Population Pharmacokinetics and Pharmacodynamics Modeling of Torasemide and Furosemide After Oral Repeated Administration in Healthy Dogs. Front Vet Sci. 2020;7:151.

40. Raj Kumar Goel PS, Shazia, Sanjay Khanna, Rakesh Kumar Dixit. Clinical Significance of Half Life of Drugs. International Journal of Pharmacotherapy. 2014;4(1):6-7.

41. Lee Y, Kim K, Kim M, Choi DH, Jeong SH. Orally disintegrating films focusing on formulation, manufacturing process, and characterization. Journal of Pharmaceutical Investigation. 2017;47(3):183-201.

42. Kim B-S, Park G-T, Park M-H, Shin YG, Cho C-W. Preparation and evaluation of oral dissolving film containing local anesthetic agent, lidocaine. Journal of Pharmaceutical Investigation. 2017;47(6):575-81.

43. USP Convention Inc. R-v, Maryland, USA. United States Pharmacopoeia XXIX2006. 1497 p.

44. Kim DH, Kim JY, Kim AM, Maharjan P, Ji YG, Jang DJ, et al. Orlistat-loaded solid SNEDDS for the enhanced solubility, dissolution, and in vivo performance. Int J Nanomed. 2018;13:7095-106.

\section{Figures}




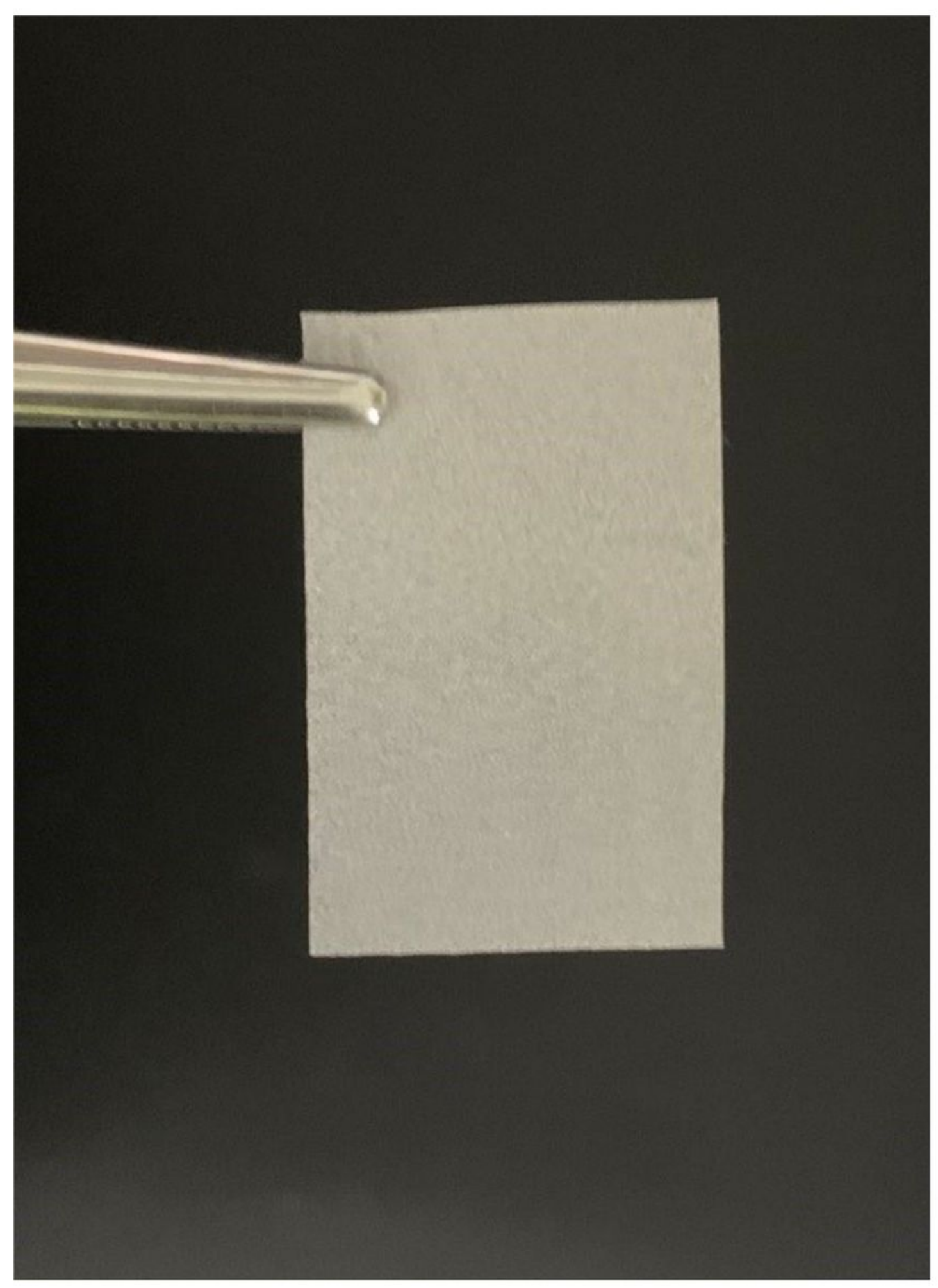

\section{Figure 1}

Title: Representative appearance of furosemide-loaded orally disintegrating film Legend: No content 


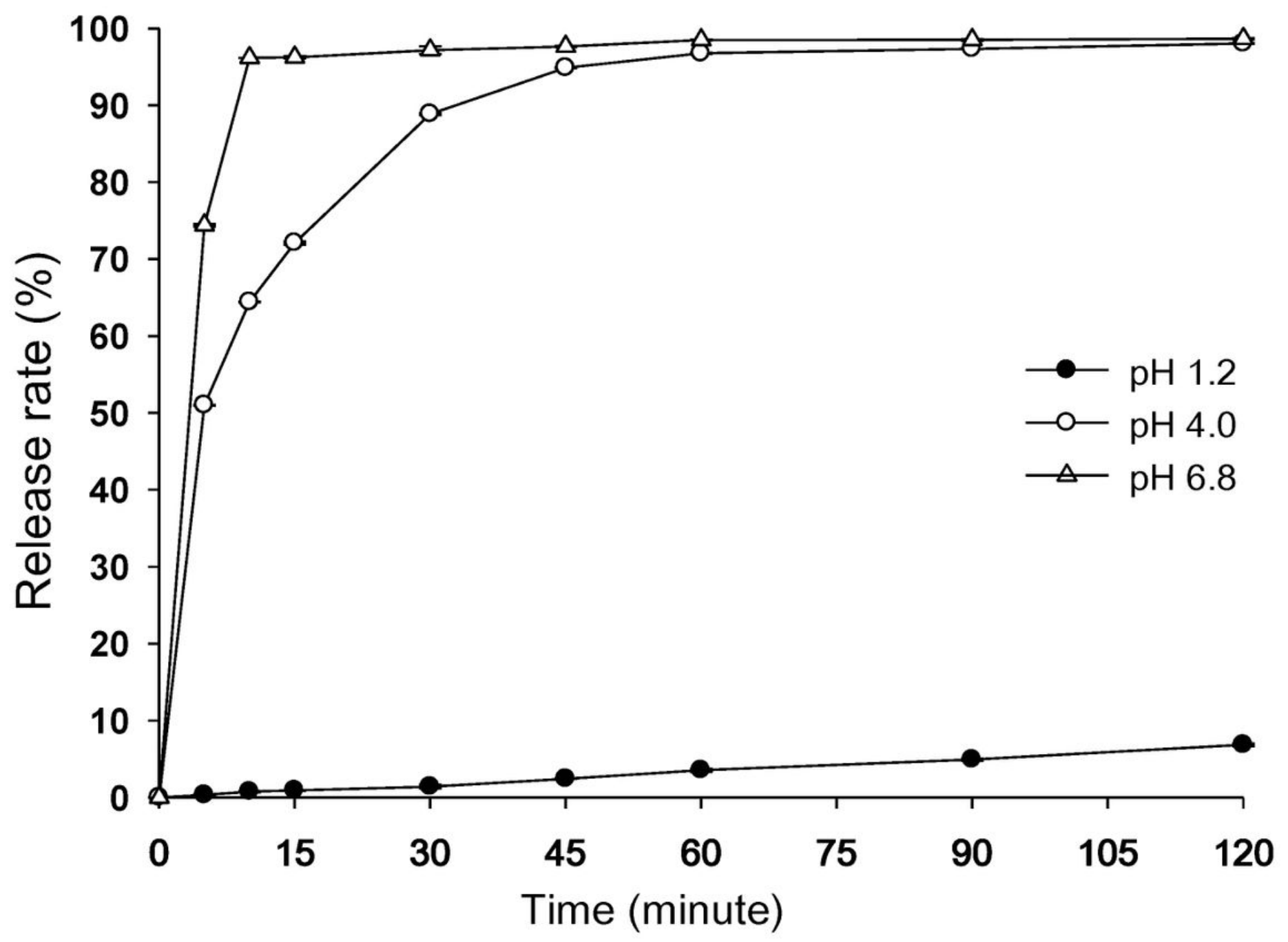

Figure 2

Title: Dissolution profiles of furosemide-loaded orally disintegrating film at $\mathrm{pH} 1.2, \mathrm{pH} 4.0, \mathrm{pH}$ 6.8. $(\mathrm{n}=4)$ Legend: No content 


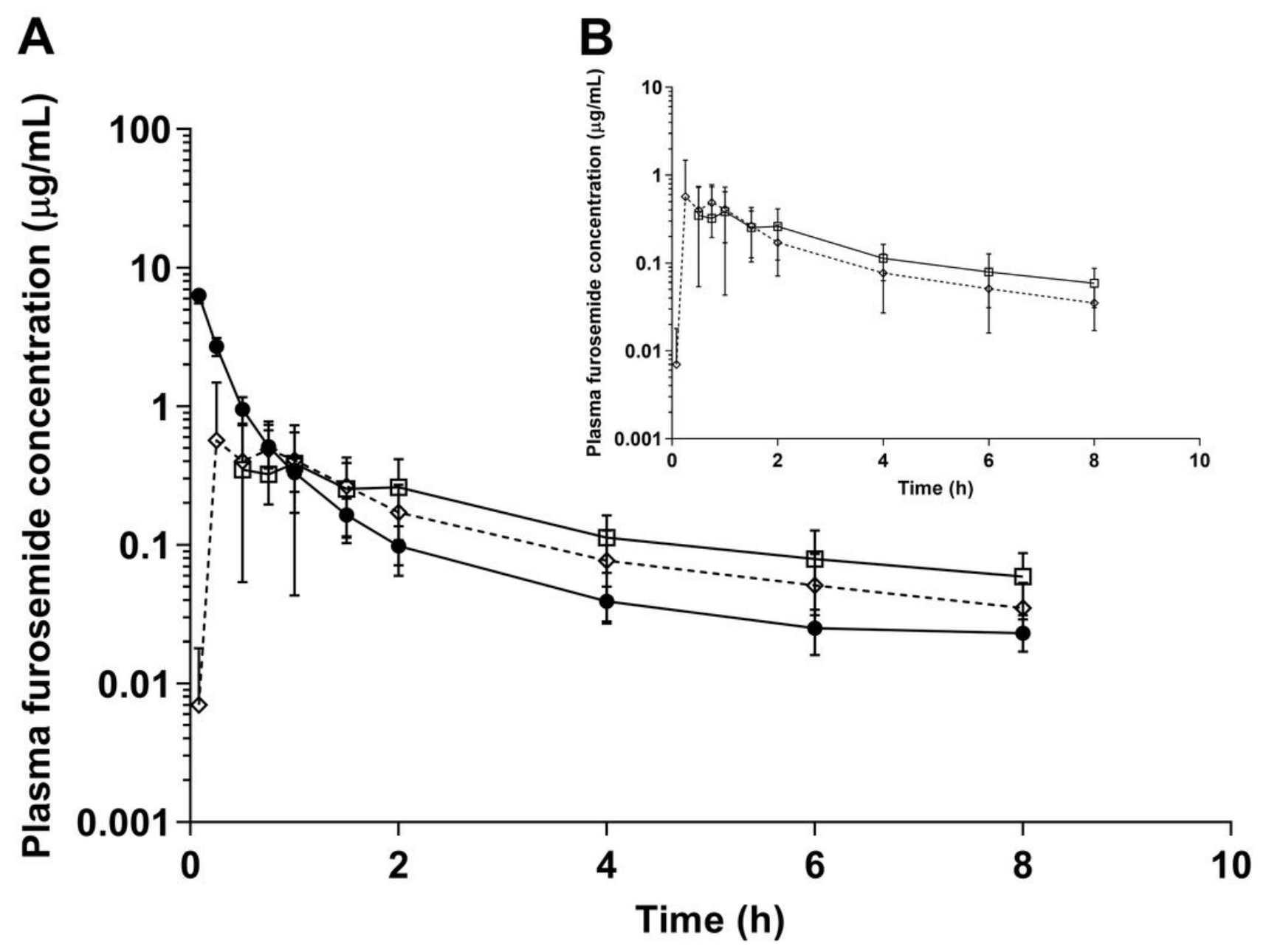

Figure 3

Title: Mean plasma furosemide concentration for each group. Legend: (A) Comparison of time course change in plasma concentration following $2 \mathrm{mg} / \mathrm{kg}$ furosemide administration in intravenously (IV), orally uncoated tablet (OUT) and furosemide-loaded orally disintegrating film (FS-ODF) group. (B) OUT and FS-ODF are represented by a line graph in figure $3(A)$. See Table 3 for pharmacokinetic constant. Values presented as mean \pm SD. IV, (๑); OUT, $(\square)$; FS-ODF, ( () 